http://dx.doi.org/10.4314/ajtcam.v12i2.9

\title{
HYDROXYMETHYL FURFURAL IN CHINESE HERBAL MEDICINES: ITS FORMATION, PRESENCE, METABOLISM, BIOACTIVITIES AND IMPLICATIONS
}

\author{
Hui-feng Gao ${ }^{1}$, Xue-sen Wen ${ }^{1 *}$, Cory J. Xian ${ }^{2}$ \\ ${ }^{1}$ Institute of Pharmacognosy, School of Pharmaceutical Sciences, Shandong University, Jinan 250012, China. ${ }^{2}$ Sansom \\ Institute for Health Research, School of Pharmacy and Medical Sciences, University of South Australia, Adelaide, SA \\ 5001, Australia.*E-mail: x.s.wen@163.com
}

\begin{abstract}
Background: Chinese herbal medicines (CHMs) must be processed before being prescribed to patients. During the processing, some CHMs became brown and as such 5-hydroxymethyl furfural (HMF) generated. Increasing attention is being paid to the safety and effectiveness of HMF. Methods: This paper summarized previous and recent reports on HMF formation, its presence in CHMs, its metabolism and bioactivities, together with its implications for CHMs.

Results: HMF had been detected in 41 CHMs, and increased by about 12 1200 times after heat processing in some CHMs. Current data showed that HMF has limited genotoxicity but various bioactivities, such as anti-oxidative, anti-apoptotic, anti-inflammatory, anti-hypoxic, anti-microbial, and inhibiting sickling of red blood cells.

Conclusion: Accumulation of HMF during heat processing of CHMs indicates that Maillard reaction and caramelization occurred. The other products of the two browning reactions deserve more attention in the following investigations on heat processed CHM.
\end{abstract}

Keywords: hydroxymethyl furfural, Chinese herbal medicine, Maillard reaction, caramelization.

\section{Introduction}

Hydroxymethyl furfural (HMF) is a typical five-member heterocyclic organic compound with a formyl group and a hydroxyl methyl group. The generation of HMF is closely related to non-enzymatic browning reactions namely Maillard reaction and caramelization (Fadel and Farouk, 2002; Quintas et al., 2007). It was found widely present in sugar-containing processed foods/drinks, such as juice (Gökmen and Acar, 1999; Damasceno et al., 2008), honey (Spano et al., 2006), coffee (Murkovic and Bornik, 2007; del Campo et al., 2010; Arribas-Lorenzo and Morales, 2010), beverages (Monakhova and Lachenmeier, 2012; Maes et al., 2012), dried fruits (Murkovic and Pichler, 2006), cookies (Ameur et al., 2006) and bread (Ramirez-Jimenez et al., 2000; 2001). Its influence on food safety has raised wide concerns and its content has been used as an index for quality control of processed foods (Cohen et al., 1998; Zappala et al., 2005; Gaspar and Lucena, 2009).

In recent years, HMF has been frequently detected in Chinese herbal medicines (CHMs), especially, in processed CHMs. CHM processing, Pao Zhi in Chinese, is a pharmaceutical technology developed about 1000 years ago, aiming to eliminate non-medicinal substances, fit clinical application by cutting the crude materials into slices of desired size, diminish toxicity and side effects, moderate drastic actions, and enhance desired therapeutic effects. Methods of Pao Zhi are nearly all derived from cooking, including steaming, stewing, roasting, baking, calcining, and stir-frying with or without adjuvants (such as honey, rice wine, vinegar, ginger juice, bran, and bean curd) (Sionneau and Flaws, 1995). Since almost all these crude drugs and adjuvants contain sugars, amino acids, proteins and/or organic acids (Jia et al., 2002; Yang et al., 2008; Zhang et al., 2009), and most of these processing methods need high temperature, Maillard reaction and/or caramelization is unavoidable, leading to accumulation of HMF in the processed CHMs.

Up to now, remarkable progress has been made in studies on the biological activity, toxicity, formation and distribution of HMF in CHMs. This current paper reviewed related reports aiming to provide a better understanding of HMF in CHMs and its potential influence on the function and safety of CHMs.

\section{Formation of HMF \\ Mechanisms of HMF formation}

HMF is mainly generated by Maillard reaction and caramelization. Maillard reaction, namely amino-carbonyl reaction, refers to the reaction between compounds with amino groups and those with carbonyl groups that finally results in the accumulation of melanoids. HMF is an intermediate product of Maillard reaction. The early stage of Maillard reaction leads to the formation of Schiff's base with amino group (Nsubstituted glycosylamine) which is subsequently transformed into Amadori product. In the advanced stage, Amadori product breaks down by three routes among which the 3-deoxyosone-pathway $(\mathrm{pH} \leq 7)$ via the 1,2 enolization leads to the formation of HMF (Hodge, 1953). In caramelization, HMF can be produced by direct dehydration of sugars like fructose and glucose, and the possible mechanism may involve two pathways: one is based on the changes of ring structure and the other occurs via simple acyclic compounds (Lewkowski, 2001). The former mechanism has been confirmed by experiments (Antal et al., 1990).

\section{Intrinsic factors influencing HMF formation}

HMF formation is closely related to the type of sugars that participate in the reaction. Generally the accumulation of HMF with sucrose being used as a substrate is apparently less than that with hexose such as fructose or glucose. However, when temperature reaches a high degree, sucrose begins to have a greater advantage as to the formation of HMF because it tends to be stable until the temperature increases to a high point, such as $300^{\circ} \mathrm{C}$, at which complete hydrolysis of sucrose occurs. The fructose and glucose released during the hydrolysis of sucrose exhibit stronger activities than pre-existing hexoses in forming HMF (Ameur et al., 2007). The formation of fructofuranosyl cation from fructose was the first step in forming HMF (Roma'n-Leshkov et al., 2006). PerezLocas and Yaylayan found that $90 \%$ of HMF originated from fructose moiety of sucrose at temperatures above $250^{\circ} \mathrm{C}$, however, when sucrose was refluxed in acidic methanol at $65{ }^{\circ} \mathrm{C}, 100 \%$ of $\mathrm{HMF}$ was generated from the glucose moiety. Under mild acidic conditions, glycosidic bond of sucrose can be easily cleaved to produce fructofuranosyl cation, and then HMF formed, however, it is much more difficult for the free fructose to generate the same cation (PerezLocas and Yaylayan, 2008). 


\section{http://dx.doi.org/10.4314/ajtcam.v12i2.9}

For hexoses, HMF formation from ketohexoses is faster than from aldohexoses. For example, fructose is superior to glucose in terms of reaction velocity. On one hand, the relative stability of the structure of glucose limits its enolization in a much greater degree, on the other hand, the oligosaccharides bearing reducing groups generated by the condensation of glucose will increase in proportions, and these newly produced oligosaccharides take part in further reactions with intermediates, such as HMF, which then gives rise to a cross-polymerization (Lewkowski, 2001). In addition, in aqueous solution the furan structure of fructose which can form fructofuranosyl cation under an acidic condition accounts for a large proportion and the furan rings of these fructofuranosyl cations then directly take part in HMF formation. By comparison, few furan structures exist in glucose, making the isomerization of glucopyranose to fructofuranose a need to form HMF. Apart from the transformation based on isomerization, glucose in certain proportion can be converted into HMF through 3-deoxyglucosone (3-DG), the intermediate formed from the open-ring structure of glucose (PerezLocas and Yaylayan, 2008). Because of the lower probability of glucose to exist in the form of open-ring as well as the complex side reactions of 3-DG, the speed of conversation into HMF is far behind that of fructose. Additionally, the formation of 3-DG usually needs amino compounds as catalysts, which is not for fructose.

\section{Extrinsic factors influencing HMF formation}

Except the intrinsic elements, the extrinsic ones such as temperature, acidity, water activity and some others also affect the production of HMF. For Maillard reaction and caramelization, temperature plays an important role in the reaction course (Ajandouz et al., 2008; Martins and Van Boekel, 2001). Usually the accumulation of HMF rises with the temperature increase, but the reverse may take place when the temperature increases to be quite high like $300^{\circ} \mathrm{C}$. This can be ascribed to the degradation of HMF into secondary products such as furaldehyde and 2methylfurfural (Ameur et al., 2008).

In a general way, lowering acidity enhances the propensity of HMF formation (Gökmen et al., 2007). In Maillard reaction, low pH facilitates the process of 1,2-enolization of Amadori products which is the crucial step in forming HMF. Therefore from the perspective of Maillard reaction, acidic condition favors the formation of HMF. As for caramelization, it always takes place under a drastic condition such as more extreme $\mathrm{pH}(\mathrm{pH}<3$ or $>9)$ (Kroh, 1994; Ajandouz et al., 2001). Wang et al. performed a study on the formation of HMF during heating treatment of the jujube juice and found that both strong acid and alkali accelerated the increase of HMF. When $\mathrm{pH}$ value was 6 , the natural $\mathrm{pH}$ value for the jujube juice, the content of HMF was the lowest (Wang et al., 2011c).

Ameur et al. found that HMF content increased with water activity reduction from 0.4 to 0 (Ameur et al., 2006). The activation energy of HMF formation during pasteurization of apple cider $(27.3 \mathrm{~kJ} / \mathrm{mol})$ (Gentry and Roberts, 2004) was much higher than that during baking cookies (10.63 kJ/mol) (Ameur et al., 2006). However, some literatures argued that HMF accumulation increased from dry state to a maximum at a water activity in the range of about 0.5-0.8 and then decreased at a higher water activity. A possible explanation for these changes was that higher water activity improved the mobility of solutes, leading to a higher reaction rate; and when water activity was up to 0.8 , dilution effect on solutes became more significant and reduced the reaction rate (Vaikousi et al., 2008; Lavelli and Vantaggi, 2009), or water behaved as a reaction product and showed an inhibitory effect (Gögüs et al., 2000).

Some cations also influence HMF formation. Gökmen and Senyuva elucidated that $\mathrm{Ca}^{2+}, \mathrm{Mg}^{2+}$, and $\mathrm{Fe}^{3+}$ effectively boosted the accumulation of HMF by glucose-asparagines reaction model. They provided a reasonable explanation for this phenomenon by a chemical mechanism implying that these cations change the reaction pathway from the formation of Schiff base to the dehydration of glucose which leads to the increase of HMF (Gökmen and Senyuva, 2007). During the process of roasting cocoa, Oliviero et al. found that the presence of catechin obviously hindered HMF forming. "Carbonyl trapping" effect of catechin refers to the reaction between catechin and carbohydrates resulting in the generation of catechin-carbohydrate compounds. The formation of these adducts reduced carbohydrates or deoxyosuloses to the pathways that lead to HMF production (Oliviero et al., 2008). Additionally, leavening agents could also influence the formation of HMF by altering the degradation of sugars (Gökmen et al., 2008).

\section{Some new methods for getting HMF from sugars}

Rosatella has reviewed many synthetic methods of HMF (Rosatella, 2011). In recent years many new optimization methods have been applied to raise the production of HMF from sugars. Okano et al. established a recycled water/acetonitrile biphasic system induced by imidazolium chlorosulfate $\left(\left[\mathrm{MBCl}_{10}\right] \mathrm{SO}_{3} \mathrm{Cl}\right)$ to accelerate the dehydration of fructose to $\mathrm{HMF}$ (Okano et al., 2013). Rajabbeigi et al. investigated different porous carbons as absorbents for selective removal of HMF from the well-known solvent dimethyl sulfoxide (DMSO) that allows for highly selective fructose dehydration to HMF (Rajabbeigi et al., 2012). Recently the selection of different catalysts as modifiers has been a hot research topic (Zhang et al., 2012b; Guan et al., 2011; Bali et al., 2012; Liu and Chen, 2013; Zhou et al., 2012a; Jadhav et al., 2012).

\section{Presence of HMF in CHMs HMF isolated from CHMs}

HMF has been isolated and identified from a wealth of CHMs (Table 1). The CHM materials used nearly all have been subjected to hot-air drying, and their isolation processes mostly undergo heat refluxing. However, whether HMF inherently exists in these CHMs and/or be newly produced in the process of drying and refluxing is still not clear.

\section{HMF in processed CHMs}

HMF is more often detected in CHMs that have been subjected to heat processing or prolonged storage. Generally speaking, the processing temperature and time, acidic conditions and the endogenous compounds such as fructose, organic acids or amino acids all exert influences on the generation and accumulation of HMF (Zhang et al., 2009). During steaming rehmannia root, HMF content increased concomitantly with the decrease of amino acids (Guo et al., 2012). Jia et al. have isolated and identified HMF from the sublimate of Cibot Rhizome and the source has been attributed to dehydration of glucose or fructose at high temperature (Jia et al., 2002). Yang et al. determined HMF in different processed products of Polygonatum and deemed that HMF was mainly derived from dehydration of reducing sugars or other polysaccharose (Yang et al., 2008). The existence of fructose, some proteins and amino acids as well as the prolonged storage can remarkably increase HMF contents in honey (Lu et al., 2006; Morales et al., 2009). 
Gao et al., Afr J Tradit Complement Altern Med. (2015) 12(2):43-54

http://dx.doi.org/10.4314/ajtcam.v12i2.9

Table 1: CHMs containing HMF

\begin{tabular}{|c|c|c|c|}
\hline Origin & Materials & Detection methods & References \\
\hline $\begin{array}{l}\text { Aucklandia lappa } \mathrm{DC} . \\
\text { [Saussurea lappa } \text { C.B Clarke] }\end{array}$ & root slice & ${ }^{1} \mathrm{H}-\mathrm{NMR}$ & Yin et al. (2005) \\
\hline Polygonatum odoratum (Mill.) Druce & rhizoma & ${ }^{1} \mathrm{H}-\mathrm{NMR},{ }^{13} \mathrm{C}-\mathrm{NMR}$ & Li et al. (2010) \\
\hline Citrus maxima (Burm.) Merr. & fruit peel & ${ }^{1} \mathrm{H}-\mathrm{NMR}$ & Feng and Pei (2000) \\
\hline Stellaria dichotoma L. var. lanceolata Bge. & root & $\begin{array}{l}\text { EI-MS, }{ }^{1} \mathrm{H}-\mathrm{NMR} \\
{ }^{13} \mathrm{C}-\mathrm{NMR}\end{array}$ & Sun et al. (2006) \\
\hline Urtica angustifolia Fisch. ex Hornem. & $\begin{array}{l}\text { aboveground } \\
\text { parts }\end{array}$ & $\begin{array}{l}\text { EI-MS, }{ }^{1} \mathrm{H}-\mathrm{NMR} \\
\mathrm{IR},{ }^{13} \mathrm{C}-\mathrm{NMR}\end{array}$ & Li et al. (2008) \\
\hline Smilax glabra Roxb. & rhizoma & ${ }^{1} \mathrm{H}-\mathrm{NMR},{ }^{13} \mathrm{C}-\mathrm{NMR}$ & Yuan et al. (2004) \\
\hline Bolbostemma paniculatum (Maxim.) Franquet & bulb & ${ }^{1} \mathrm{H}-\mathrm{NMR}$ TLC & Zheng et al. (2005) \\
\hline Liquidambar orientalis Mill. & resin & ${ }^{1} \mathrm{H}-\mathrm{NMR}$ & Wang et al. (2011a) \\
\hline $\begin{array}{l}\text { Rosa bracteata J. C. Wendl. } \\
\text { [Rosa bracteata } \text { Wendl. var. bracteata.] }\end{array}$ & fruit & $\begin{array}{l}{ }^{1} \mathrm{H}-\mathrm{NMR},{ }^{13} \mathrm{C}-\mathrm{NMR}, \\
\mathrm{MS}, \mathrm{IR}, \mathrm{UV}\end{array}$ & Yuan and Du (2000) \\
\hline $\begin{array}{l}\text { Acorus calamus L. var. angustatus Besser } \\
\text { [Acorus tatarinowii Schott] }\end{array}$ & rhizoma & ${ }^{1} \mathrm{H}-\mathrm{NMR},{ }^{13} \mathrm{C}-\mathrm{NMR}$ & $\begin{array}{l}\text { Tong and Cheng } \\
(2011)\end{array}$ \\
\hline $\begin{array}{l}\text { Elaeagnus rhamnoides }(\mathrm{L} .) \text { A.Nelson } \\
\text { [Hippophae rhamnoides L.] }\end{array}$ & fresh fruit & ${ }^{1} \mathrm{H}-\mathrm{NMR}$ & Dang et al. (2007) \\
\hline $\begin{array}{l}\text { Sparganium stoloniferum (Buch.-Ham. ex Graebn.) Buch.-Ham. ex Juz. } \\
\text { [Sparganium stoloniferum Buch.-Ham.] }\end{array}$ & tuber & $\begin{array}{l}\text { ESI-MS, }{ }^{1} \mathrm{H}-\mathrm{NMR}, \\
{ }^{13} \mathrm{C}-\mathrm{NMR}\end{array}$ & An et al. (2009) \\
\hline Millettia specisoa Champ. & root & $\begin{array}{l}\text { ESI-MS, }{ }^{1} \mathrm{H}-\mathrm{NMR}, \\
{ }^{13} \mathrm{C}-\mathrm{NMR}\end{array}$ & Wang et al. (2008) \\
\hline Descurainia sophia (L.) Webb ex Prantl & seed & ${ }^{1} \mathrm{H}-\mathrm{NMR},{ }^{13} \mathrm{C}-\mathrm{NMR}$ & Sun et al. (2005) \\
\hline Ranunculus ternatus Thunb. & tuberous root & $\begin{array}{l}\text { ESI-MS }{ }^{1} \mathrm{H}-\mathrm{NMR}, \\
{ }^{13} \mathrm{C}-\mathrm{NMR}\end{array}$ & Chen et al. (2005) \\
\hline $\begin{array}{l}\text { Ophiopogon japonicus (Thunb.) Ker Gawl. } \\
\text { [Ophiopogon japonicus (L. f.) Ker-Gawl.] }\end{array}$ & tuberous root & ${ }^{1} \mathrm{H}-\mathrm{NMR},{ }^{13} \mathrm{C}-\mathrm{NMR}$ & Wang et al. (2009b) \\
\hline [Zantedeshia aethiopica $(\mathrm{L})$ Spreng] & herb & $\begin{array}{l}\text { UV, GC-MS, } \\
{ }^{1} \mathrm{H}-\mathrm{NMR}, \mathrm{IR}\end{array}$ & Yang et al. (2009) \\
\hline Humulus scandens (Lour.) Merr. & herb & $\begin{array}{l}\text { ESI-MS, }{ }^{1} \mathrm{H}-\mathrm{NMR}, \\
{ }^{13} \mathrm{C}-\mathrm{NMR}\end{array}$ & Cao (2012) \\
\hline $\begin{array}{l}\text { Pyrola calliantha Andres } \\
\text { [Pyrola calliantha } \text { H. Andres] }\end{array}$ & herb & $\begin{array}{l}\text { ESI-MS, }{ }^{1} \mathrm{H}-\mathrm{NMR}, \\
{ }^{13} \mathrm{C}-\mathrm{NMR}\end{array}$ & Ren et al. (2010) \\
\hline Euphorbia hylonoma Hand.-Mazz. & root & ${ }^{1} \mathrm{H}-\mathrm{NMR},{ }^{13} \mathrm{C}-\mathrm{NMR}$ & Guo et al. (2007) \\
\hline Carthamus tinctorius $\mathrm{L}$. & tubular petal & ${ }^{1} \mathrm{H}-\mathrm{NMR},{ }^{13} \mathrm{C}-\mathrm{NMR}$ & Zhou et al. (2007) \\
\hline [Cynanchum amplexicaule Sieb. et Zucc.] & root and rhizoma & ${ }^{1} \mathrm{H}-\mathrm{NMR}, \mathrm{TLC}$ & Chen et al. (2008) \\
\hline $\begin{array}{l}\text { Drynaria roosii Nakaike } \\
\text { [Drynaria fortune (Kunze) J. Sm.] }\end{array}$ & rhizoma & ${ }^{1} \mathrm{H}-\mathrm{NMR}$ & Shang et al. (2010) \\
\hline Heterosmilax yunnanensis Gagnep. & rhizome slice & ${ }^{1} \mathrm{H}-\mathrm{NMR}$ & Qin et al. (2007) \\
\hline Cremastra appendiculata (D. Don) Makino & pseudobulb & ${ }^{1} \mathrm{H}-\mathrm{NMR},{ }^{13} \mathrm{C}-\mathrm{NMR}$ & Zhang et al. (2007) \\
\hline $\begin{array}{l}\text { Sauromatum giganteum (Engl.) Cusimano \& Hett. } \\
\text { [Typhonium giganteum Engl.] }\end{array}$ & corm & ${ }^{1} \mathrm{H}-\mathrm{NMR},{ }^{13} \mathrm{C}-\mathrm{NMR}$ & $\begin{array}{l}\text { Shi et al. (2010) } \\
\text { Zhang et al. (2010) }\end{array}$ \\
\hline Clematis terniflora var. manshurica (Rupr.) Ohwi [Clematis manshurica Rupr.] & root and rhizoma & $\begin{array}{l}\text { EI-MS, }{ }^{1} \mathrm{H}-\mathrm{NMR}, \\
{ }^{13} \mathrm{C}-\mathrm{NMR}\end{array}$ & Shi et al. (2007) \\
\hline Angelica acutiloba (Siebold \& Zucc.) Kitag. & root & $\begin{array}{l}\text { EI-MS, IR, }{ }^{1} \mathrm{H}-\mathrm{NMR}, \quad{ }^{13} \mathrm{C}- \\
\text { NMR }\end{array}$ & Liu et al. (2011) \\
\hline Hordeum vulgare $\mathrm{L}$. & malt & ${ }^{1} \mathrm{H}-\mathrm{NMR}, \mathrm{TLC}$ & Ling et al. (2005) \\
\hline $\begin{array}{l}\text { Melia azedarach } \mathrm{L} . \\
\text { [Melia toosendan Sieb. et Zucc.] }\end{array}$ & fruit & ESI-MS, ${ }^{1} \mathrm{H}-\mathrm{NMR}$ & Xie et al. (2008) \\
\hline $\begin{array}{l}\text { Pinellia ternata (Thunb.) Makino } \\
{[\text { Pinellia ternata }(\text { Thunb.) Breit.] }}\end{array}$ & corm & $\begin{array}{l}\text { EI-MS, }{ }^{1} \mathrm{H}-\mathrm{NMR}, \\
{ }^{13} \mathrm{C}-\mathrm{NMR}\end{array}$ & Yang et al. (2007) \\
\hline Castanea mollissima Blume & seed & ${ }^{1} \mathrm{H}-\mathrm{NMR}$ & Zhang et al. (2008a) \\
\hline $\begin{array}{l}\text { Isatis tinctoria } \mathrm{L} . \\
\text { [Isatis indigotica Fort.] }\end{array}$ & root extract & TLC & Liu et al. (2002) \\
\hline $\begin{array}{l}\text { Atractylodes lancea (Thunb.) DC. } \\
\text { [Atractylodes chinensis (DC.) Koidz.] }\end{array}$ & rhizoma slice & ${ }^{1} \mathrm{H}-\mathrm{NMR}, \mathrm{TLC}$ & Li et al. (2003) \\
\hline Coniogramme japonica (Thunb.) Diels & root and rhizoma & EIS-MS, ${ }^{1} \mathrm{H}-\mathrm{NMR}$ & Fang et al. (2010) \\
\hline $\begin{array}{l}\text { Sinopodophyllum hexandrum (Royle) T.S.Ying [Sinopodophyllum emodi (Wall. } \\
\text { Ying.] }\end{array}$ & root and rhizoma & ${ }^{1} \mathrm{H}-\mathrm{NMR},{ }^{13} \mathrm{C}-\mathrm{NMR}$ & Sun et al. (2012) \\
\hline Inula racemosa Hook. f. & root & EIS-MS, ${ }^{1} \mathrm{H}-\mathrm{NMR}$ & $\begin{array}{l}\text { Zhang and Chen } \\
(2011)\end{array}$ \\
\hline
\end{tabular}

The names of plants have recently been accepted according to the website of The Plant List, and the names within square brackets are derived from original reports.

Apart from the factors mentioned above that affect contents of HMF in CHMs, different processing methods also influence HMF contents. HMF in steamed fruit of Cornus officinalis was more than the one pretreated with rice wine (Du et al., 2008). For the fruit of Ligustri lucidi, HMF content in the water-steamed sample was higher than the wine-steamed sample, but lower than the wine-stewed one (Cao et al., 2009). Rice wine, vinegar and honey can indirectly increase the content of HMF as they contain certain amounts of HMF (Theobald et al., 1998; Chen and Huang, 2010; Chen et al., 2009; Zhou et al., 2012b). Zhang et al. reported that HMF content in fried coix seeds without adjuvants was only about 7 times the amount of that in crude sample, while in bran fried coix seeds HMF content increased by 30 times, which was ascribed to Maillard reaction between sugars and amino acids in wheat bran (Zhang et al., 2012a). Overall, due to the existence of sugars and amino acids in $\mathrm{CHM}$, heat treatment at a high temperature for a longer time will greatly contribute to the formation of HMF. 
HMF could be readily absorbed from gastrointestinal tract in rats and mice (Godfrey et al., 1999), and HMF that was left unabsorbed could be transformed by enteric bacterial strains to 5-hydroxymethylfurfuryl alcohol, an intermediate metabolite (Boopathy et al., 1993). As such, toxicity caused by HMF may be reduced to a great extent as enteric bacteria can tolerate a higher concentration of 5-hydroxymethylfurfuryl alcohol. Godfrey et al. demonstrated that HMF could be metabolized rapidly in liver and kidney and excreted primarily via urine in rats and mice, and the majority of metabolites excreted was 5-hydroxmethyl-2-furoic acid (HMFA) followed by much lesser proportions of 2,5-furan dicarboxylic acid (FDCA) and N-(5-hydroxymethyl-2-furoyl) glycine (HMFG) (Godfrey et al., 1999). In human body, HMFA excreted via urine has been demonstrated to correlate well with HMF intake from food (Husøy et al., 2008). Jobstl et al. analyzed three hundred urine samples and showed that the concentration of HMFA in urine varied from 0 to $100 \mathrm{mg} / \mathrm{L}$ among which the majority was around $10 \mathrm{mg} / \mathrm{L}$ (Jobstl et al., 2010 ). Apart from HMFA, FDCA and HMFG have also been detected in human urine (Pettersen and Jellum, 1972). In addition, HMF can also be metabolized to sulfooxymethylfurfural (SMF), which has been proven to induce genotoxicity (Monien et al., 2009).

\section{Bioactivities of HMF}

For a long time, whether HMF is beneficial (a "friend") or harmful (a "foe") to human health has been a matter of debate. While HMF is still regarded as a strictly controlled ingredient in many foods (Cohen et al., 1998; Zappala et al., 2005; Gaspar et al., 2009), a growing number of studies have demonstrated that HMF is an active constituent in some CHMs. For instance, HMF was proven to be the main active component in steamed rehmannia root to improve erythrocyte deformability (Matsuda et al., 2004) and shown to play an important role in the anti-tumor metastasis property of Ardisia crenata (Wang et al., 2011). In addition, many beneficial effects of Fructus corni were also considered to be related to HMF (Ding et al., 2010; Wang et al., 2010; Zhang et al., 2008).

\section{Anti-oxidative and anti-apoptotic activity}

Oxidative stress appears when the balance between generation and elimination of reactive oxygen species (ROS) is disturbed. Production of ROS including free radicals and peroxides is a destructive aspect of oxidative stress. Severe oxidative stress can trigger cell apoptosis (Verhaegen et al., 1995) and necrosis. Many enzymes in a living body are positive cellular antioxidants, including superoxide dismutase (SOD), catalase (CAT) and glutathione peroxidase (GSH-Px).

HMF was shown to alleviate high fat diet-induced oxidative damage to plasma and liver of mice by maintaining the levels of blood lipids, CAT, GSH-Px and reducing levels of ROS and malonaldehyde (Song et al., 2010). Additionally, HMF attenuated hydrogen peroxideinduced hippocampal neuronal injury, reducing the activity of lactic dehydrogenase and increasing that of SOD (Gu et al., 2011a). Similarly, due to the ability of reducing free radical levels and enhancing activity of SOD, HMF prolonged the survival of mice with permanent forebrain ischemia (Ya et al., 2012) and improved dysmnesia induced by cerebral ischemia and reperfusion (Zhang et al., 2007). In an in vitro study, Sharma et al. verified the antioxidative activity of HMF in suppressing tyrosinase in mushroom Dictyophora indusiata (Sharma et al., 2004).

As a potent antioxidant, HMF can resist oxidative stress-induced apoptosis. HMF prevented high glucose-induced oxidative stress in human umbilical vein endothelial cells mainly by rapidly balancing the levels and functions of the apoptosis-related Jun N-kinase1, Jun N-kinase2/3, plasma interleukin-8 (IL-8), phosphorylated protein kinase B (p-Akt) and ROS (Cao et al., 2013). HMF was considered to be an active component of processed Fructus corni for its protection of human LO2 hepatocytes from hydrogen peroxide injury-induced cell morphological change (Wang et al., 2010) and apoptosis (Ding et al., 2010), through its action in maintaining the cell cycle and in reducing nitric oxide release and activity of caspase-3 (Ding et al., 2010).

\section{Pro-inflammatory or anti-inflammatory effect}

Inflammation is part of complex biological responses of various tissues to harmful stimuli, such as pathogens, damaged cells, or irritants. Inflammatory mediators derived from cells such as prostaglandin (PG) (Humes et al., 1977), nitric oxide (NO) (Kröncke et al., 1998), tumor necrosis factor-alpha (TNF- $\alpha$ ) (Balkwill and Mantovani, 2001) and IL-8 (Baggiolini and Clark-Lewis, 1992) play significant roles in regulation of inflammatory responses. Uncontrolled inflammation can lead to tissue damages and are often involved in many immune system diseases, like allergic reaction (Galli et al., 2008) and some myopathies.

$\mathrm{HMF}$ isolated from Litchi chinensis was found to moderately stimulate the release of $\mathrm{PGE}_{2}$ and $\mathrm{NO}$ in murine J774 macrophages by activating nuclear factor kappa $\mathrm{B}(\mathrm{NF}-\kappa \mathrm{B}$, a transcription factor known extensively involved in inflammation) and promoting mRNA expression of cyclooxygenase-2 (an enzyme responsible for PG formation) and inducible nitric oxide synthase (iNOS) (an enzyme catalyzing production of NO) (Zhou et al., 2012c). Whilst this finding suggests the potential pro-inflammatory effect of HMF, more reports have indicated the antiinflammatory effect of HMF. Kim et al. found that HMF could significantly suppress the protein and mRNA expression of vascular cell adhesion molecule-1 and intercellular cell adhesion molecule-1 in TNF- $\alpha$ stimulated human umbilical vein endothelial cells by inhibiting NF- $\kappa$ B activation and production of ROS (Kim et al., 2011). In addition, HMF was identified as a potent inhibitor of xanthine oxidase, which interacts with Tolllike receptor-4 and leads to activation of NF- $\kappa \mathrm{B}$ and then production of NF- $\kappa \mathrm{B}$ dependent proinflammatory cytokines including TNF- $\alpha$ and macrophage inhibitory protein-2 (Lorne et al., 2008; Lin et al., 2012). Du et al. reported that HMF and its derivatives could significantly inhibit TNF- $\alpha$ or IL-1 $\beta$ expression (Du et al., 2005). Kitts et al. also proved that HMF could suppress the expression of iNOS, IL-8 and other related

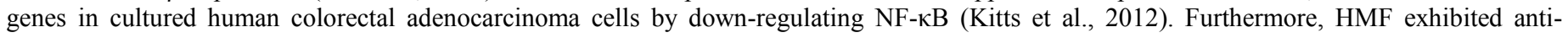
allergic effect by inhibiting the $\beta$-hexosaminidase (a chemical mediator) release at antigen-antibody binding stage and antibody-receptor binding stage (Yamada et al., 2011). Since ROS participates in inflammatory responses such as influencing NF- $\kappa$ B and up-regulating cell adhesion molecules (Vorbach et al., 2003), the ROS scavenging activity of HMF also supports its anti-inflammatory effects.

\section{Anti-hypoxic effect}

Hypoxic injures appear when oxygen supply is insufficient for the body or regions of the body. While rapid or severe hypoxia can result in detrimental events including coma, seizure, loss of consciousness and death, a hypoxic environment such as high altitude can cause maladaptive responses leading to various forms of acute altitude illness, such as acute mountain sickness, high altitude cerebral oedema and high-altitude pulmonary oedema (Wilson et al., 2009). Interestingly, the survival time and survival rate of mice exposed to acute hypobaric hypoxic condition 


\section{http://dx.doi.org/10.4314/ajtcam.v12i2.9}

Table 2 Effects of processing temperature and time on HMF accumulation in CHMs $\left(\mathbf{m g} \cdot \mathrm{kg}^{-1}\right)$

\begin{tabular}{|c|c|c|c|c|c|c|c|c|c|c|c|c|c|c|c|}
\hline \multirow{2}{*}{ Samples } & \multirow{2}{*}{ Processing methods } & \multirow{2}{*}{$\begin{array}{l}\text { Temperature } \\
\left({ }^{\circ} \mathbf{C}\right)\end{array}$} & \multicolumn{12}{|c|}{ Heating time (h) } & \multirow{2}{*}{ References } \\
\hline & & & 0 & 4 & 8 & 9 & 10 & 16 & 24 & 32 & 40 & 48 & 52 & 72 & \\
\hline \multirow{2}{*}{ Linden honey } & \multirow{2}{*}{ Heating } & 30 & 67.45 & 67.45 & 67.45 & & & 67.43 & 67.44 & & & & & & \multirow{2}{*}{$\begin{array}{l}\text { Zeng et al. } \\
\quad(2002)\end{array}$} \\
\hline & & 80 & 67.45 & 180.45 & 248.56 & & & 503.97 & 785.5 & & & & & & \\
\hline Buckwheat honey & Heating & 90 & 4.19 & $>100$ & $>600$ & & $>1000$ & & & & & & & & Lu et al. (2006) \\
\hline \multirow{2}{*}{ Chinese date honey } & \multirow{2}{*}{ Heating } & 40 & 8.98 & 9.58 & 9.73 & & 9.73 & & & & & & & & \multirow{2}{*}{$\begin{array}{l}\text { Zeng et al. } \\
\text { (2006) }\end{array}$} \\
\hline & & 80 & 8.98 & 31.1 & 77.89 & & 140.1 & & & & & & & & \\
\hline \multirow{4}{*}{ Rehmanniae radix } & \multirow{4}{*}{ Steaming } & 100 & 200 & 400 & 900 & & & 1300 & 3500 & 4300 & 5600 & 6800 & 5700 & & Li et al. (2005) \\
\hline & & 100 & 100 & & 900 & & & 1490 & & & & & & & \multirow{2}{*}{ Liu et al. (1995) } \\
\hline & & $130(140 \mathrm{Kp})$ & 100 & & 5360 & & & 11040 & & & & & & & \\
\hline & & 100 & 4.8 & 54.9 & 96.3 & & & 542.9 & 1719.2 & 2988.9 & 4216.1 & 5308.1 & 5625.9 & & Guo et al. (2012) \\
\hline \multirow{2}{*}{$\begin{array}{l}\text { Polygoni multiflori } \\
\text { radix }\end{array}$} & $\begin{array}{l}\text { Stewing with fermented soya-bean } \\
\text { milk }\end{array}$ & 100 & & & 38 & & & 136 & 407 & 653 & 973 & 1710 & & & Liu et al. (2008) \\
\hline & Steaming & 100 & & & & & & & & 475.3 & 681.6 & & & 895.6 & $\begin{array}{c}\text { Chen et al. } \\
(2012)\end{array}$ \\
\hline Scrophulariae radix & Steaming & 100 & 300 & & & 6600 & & & & & & & & & Cao et al. (2012) \\
\hline
\end{tabular}




\section{http://dx.doi.org/10.4314/ajtcam.v12i2.9}

were increased by pretreatment with HMF, as it ameliorated acute hypobaric hypoxia-induced permeability of blood-brain barrier and the extents.of cellular damage in the hippocampus and the cortex ( $\mathrm{Li}$ et al., 2011a). While hypoxia is known to induce decline in mitochondria membrane potential (MMP) (Seol et al., 2009; Wang et al., 2009a), cell necrosis/apoptosis (Saikumar and Venkatachalam, 2003) and activation of extracellular signal-regulated kinase (ERK) (Mishra et al., 2004), HMF was found to attenuate hypoxic injury by effectively suppressing the decline of MMP and the ERK phosphorylation ( $\mathrm{Li}$ et al., 2011b). In addition, HMF could increase tolerance to normobaric severe hypoxia without an adaptation process by enhancing hemoglobin $\mathrm{O}_{2}$ affinity and improving hemodynamics and oxygenation (Yalcin and Cabrales, 2012).

\section{Inhibiting sickling of red blood cells}

Sickle-cell disease is a blood disorder characterized by the sickle shape of red blood cells and is caused by a mutation of hemoglobin gene. Due to the fact that heterocyclic aldehydes are prone to form Schiff base adducts with the N-terminal $\alpha$ Val1 nitrogens of hemoglobin (Zaugg et al., 1997), five-member heterocyclic aldehydes can bind to and stabilize the relaxed state hemoglobin; and they can also bind to and destabilize the tense state hemoglobin and then inhibit red cell sickling by allosterically shifting oxygen equilibrium curves toward the left (Safo et al., 2004). HMF possesses the structural basis for the above bindings and thus can be regarded as candidates for therapy of sickle cell disease. Pretreatment of transgenic sickle mice with HMF was found to remarkably inhibit formation of sickle cells and no adverse effects were detected on red blood cells (Abdulmalik et al., 2005). Binding of HMF to hemoglobin was found to not only increase the oxygen affinity of both normal and sickle hemoglobin but also to inhibit polymerization and formation of fibrous precipitates of the sickled hemoglobin (Lin et al., 2008). Moreover increased hemoglobin-oxygen affinity seemed to yield improved microvascular function and optimize the overall process of oxygen delivery by performing targeted oxygen delivery, preferentially releasing oxygen in regions with low $\mathrm{P}_{\mathrm{O} 2}$ and bypassing delivery to oxygenated areas (Villela et al., 2009). The above studies have indeed indicated the strong potential of HMF for treating sickle cell anemia, and currently it is used in clinical trials (Lin et al., 2008).

\section{Anti-microbial effects}

For a long time, the adverse effects of HMF on the growth of microorganisms have been noticed. HMF has been confirmed as one of active constituents in Thompson seedless raisins for restraining Streptococcus mutans and Porphyromonas gingivalis, two oral pathogens associated with caries and periodontal disease (Rivero-Cruz et al., 2008). As such, antibacterial compounds derived from plants have been suggested as alternative options or may be a better choice for dental plaque and oral disease control when compared to commonly used chemicals. In addition, due to its ability of inhibiting the three important metabolism enzymes (alcohol dehydrogenase, aldehyde dehydrogenase and pyruvate dehydrogenase) (Modig et al., 2002), HMF was found to inhibit the fermentation of Saccharomyces cerevisiae and itself was primarily converted into 5-hydroxymethylfurfuryl alcohol (Taherzadeh et al., 2000; Modig et al., 2002; Ak1lloglu et al., 2011). Consistently, glucose consumption as well as ethanol yield dramatically declined in the presence of HMF at concentrations at $1 \mathrm{~g} / \mathrm{L}$ or higher during fermentation of yeast (Wikandari et al., 2010). In view of the undesired inhibitory actions of HMF during bioethanol or biofuel fermentation production process, more tolerant yeast strains have been screened for the fermentation procedures (Liu et al., 2005). Sehnem et al. found that HMF could increase the expression levels for genes ADH7 and ARI1 in Saccharomyces cerevisiae strain P6H9 which was supposed to be responsible for the strong tolerance to HMF during bioethanol production (Sehnem et al., 2013).

\section{Carcinogenic or Anti-carcinogenic action}

Some Maillard reaction products (MRPs) are known to enhance the proliferation of human tumor cells, and there also exist some MRPs which bring about quite opposite effect (Marko et al., 2002; 2003). As one of MRPs, the carcinogenicity of HMF has long caused a quite stir in the research fields. Acher et al. reported that HMF consumption was associated with the increased occurrence of azoxymethane-induced aberrant crypt foci and microadenoma in the colon of treated rats (Acher et al., 1992). Similarly, Svendsen et al. found HMF increased the number of small adenomas in the intestine of Min/+ mice (Svendsen et al., 2009). On the contrary, Groke et al. invented an agent containing HMF that had a destructive effect on malignant tumors (Groke et al., 2010). Wang et al. isolated HMF from Ardisia crenata and found its inhibitory effect on tumor metastasis (Wang et al., 2011d). Some desirable therapeutic outcomes of HMF have also been reported in hormone-refractory and chemoinsensitive metastatic cancer (Michail et al., 2007). In addition, HMF was found selectively inhibiting the activities of mammalian DNA polymerase $\lambda$ and terminal deoxynucleotidyltransferase in vitro (Mizushina et al., 2006). While some antitumor drugs targeting to DNA polymerase have been screened ( $\mathrm{Li}$ et al., 1993), further studies could potentially explore the ability of HMF inhibiting DNA polymerase for the possibility of cancer treatment.

\section{Improvement of learning and memory}

The neural damage at the hippocampus (a brain region known involved with learning and memory function) is an important cause for the deterioration of learning and memory function of senile bodies. Zhang and Jin reported that HMF in Rehmannia glutinosa could protect hippocampal neurons against corticosterone-induced injuries by up-regulating the expression of glucocorticoid receptor (GCR), brain-derived neurotrophic factor (BDNF) and glucocorticoid-regulated protein kinase (SGK) (Zhang and Jin, 2012). Gu et al. found that HMF in processed Fructus corni could restrain the apoptosis of cultured hippocampal neurons by increasing the expression of B-cell lymphoma 2 (Bcl-2, an antiapoptotic molecule) and decreasing the expression of NF- $\mathrm{KB}$ ( $\mathrm{Gu}$ et al., 2011b). These studies suggest that HMF may likely to play an advantageous role in reinforcing learning and memory or reducing their impairment.

\section{Genotoxicity}

Given the presence of HMF in the processed foods and CHMs, potential genotoxicity of HMF has widely raised safety concerns. In recent years, while extensive work has been done investigating the genotoxicity of HMF, data are always inconsistent.

The genotoxicity of HMF was regarded to be activated by sulfotransferase (SULT1A1) (Glatt et al., 2005), which is expressed widely (Alnouti and Klaassen, 2006), especially in liver (Glatt and Meinl, 2004). SULT1A1 can promote the transformation of HMF into SMF, a compound capable of inducing gene mutations via binding with DNA to form adducts (Surh and Tannenbaum, 1994; Monien et al., 2009). Monien et al. 


\section{http://dx.doi.org/10.4314/ajtcam.v12i2.9}

have further identified the DNA adducts as $\mathrm{N}^{6}$-((2-formylfuran-5-yl)methyl)-2' -deoxyadenosine and $\mathrm{N}^{2}$-((2-formylfuran-5-yl)methyl)-2'deoxyguanosine, although these adducts could not be detected until $200 \mathrm{mM}$ HMF was used (Monien et al., 2012). However, Durling et al. reported that the genotoxicity of HMF was not correlated with the activity of SULT1A1 as $100 \mathrm{mM}$ HMF induced the most prominent DNA damage in cell lines with the lowest activities of SULT1A1 (L5178Y and Caco-2) but otherwise induced the lowest level of DNA damage in cell lines with the highest activity of SULT1A1 (HEK293) (Durling et al., 2009).

DNA damage can be reflected by SOS response in which the cell cycle is arrested and DNA repair and mutagenesis are induced. Assessment on SOS response by the umu assay (Umu Chromotest) in Salmonella typhimurium TA1535/pSK1002 in presence of HMF indicated that the genotoxicity of HMF ( $\geq 12 \mathrm{mM}$ ) was fairly low (Janzowski et al., 2000). By the Salmonella microsome assay, examination of possible mutagenic effects of HMF on the Salmonella typhimurium indicator strains TA98 and TA102 revealed the lack of obvious mutagenicity of HMF (Cheriot et al., 2009). Severin et al. used five strains including four Salmonella typhimurium strains and Escherichia coli WP2uvrapKM101 to test the genotoxicity of HMF and found no genotoxic potential of HMF at the highest concentration (5000 $\mu \mathrm{g} / \mathrm{plate})$ (Severin et al., 2010). They also tested the genotoxicity of HMF by hepatocellular carcinoma (HepG2) cells and found that HMF induced DNA damage at concentrations from 7.87 to 25 $\mathrm{mM}$ in comet assay (Severin et al., 2010). The discrepancy between these results may be attributed to the involvement of SULT1A1 in HepG2 cells. These studies suggest that, depending on cells and assays used, potential genotoxicity effect of HMF is inconsistent.

\section{Other activities}

Apart from those mentioned above, HMF also exhibits some other activities. For example, HMF can effectively protect nerve cells against injury induced by sodium azide (Zhang et al., 2008c) and okadaic acid (Zhang et al., 2008b) due to its ability to reduce $\beta$-amyloid (A $\beta$ ) build-up and protect cytoskeleton system. It has been reported that HMF can also inhibit the accumulation of lipid in mouse 3T3-L1 preadipocyte cells (Matsuda et al., 2006). HMF was also identified as the active constituent in Acori tatarinowii to effectively relieve fatigue (Zhu et al., 2012). Hou et al. found that HMF could significantly enhance the absorption of glycyrrhetic acid, a metabolite of glycyrrhizin and a chief constituent of Glycyrrhiza glabra (liquorice) root (Hou et al., 2005). Furthermore, Miyazawa et al. demonstrated that HMF had strong insecticidal activity against larvae of Drosophila melanogaster (Miyazawa et al., 2003).

\section{Conclusion and implications of HMF in CHMs}

In conclusion, HMF is widely distributed in CHMs, especially in those heat processed ones due to Maillard reaction and/or caramelization. According to the available data, its toxicity can be considered to be limited at currently prescribed dosages, and its various bioactivities are undeniable. However, whether HMF is responsible for the newly generated functions in the processed CHMs still remains largely unknown. In addition, while HMF is merely an intermediate formed out of these two complicated reactions, none of its end products melanoids have been characterized in CHMs up to now (Wang et al., 2011b), beneficial effects of melanoids have been well documented (Rufián-Henares et al., 2007a; 2007b; 2008; 2009; Wang et al., 2011b). It is possible that melanoids may be more important than HMF in mediating the newly formed actions for processed CHMs, a possibility that requires future investigations.

Although the doctrines of CHM processing are not only elusive to Western world but also to most Chinese as they were formed about 1000 years ago, the existing processing methods could not be simply considered as pseudoscience. This is because the irrational preparations and formula must have been eliminated by thousands of years of clinical practices. Although some previous studies have observed heating time- and temperature- dependent effects of some processing methods on HMF contents (Table 2), more studies are required to investigate optimal CHM processing method(s) for obtaining a desirable accumulation of HMF. Further research on Maillard reaction and caramelization may be helpful to unravel the mysteries of traditional Chinese medicines and their processing for better treatment effects.

\section{Acknowledgement}

This work was financially supported by National Natural Science Foundation of China (81072984) and China-Australia Centre for Health Sciences Research.

\section{References}

1. Abdulmalik, O., Safo, M.K., Chen, Q., Yang, J., Brugnara, C., Ohene-Frempong, K., Abraham ,

D.J. and Asakura, T. (2005). 5Hydroxymethyl-2-furfural modifies intracellular sickle haemoglobin and inhibits sickling of red blood cells. Br. J. Haematol. 128 : $552-561$.

2. Ajandouz, E.H., Desseaux, V., Tazi, S. and Puigserver, A. (2008). Effects of temperature and pH on the kinetics of caramelisation, protein cross-linking and Maillard reactions in aqueous model systems. Food Chem. 107: 1244-1252.

3. Ajandouz, E.H., Tchiakpe, L.S., Ore, F.D., Benajiba, A. and Puigserver, A. (2001). Effects of pH on caramelization and Maillard reaction kinetics in fructose-lysine model systems. J. Food Sci. 66: 926-931.

4. Akıllıglu, H.G., Mogol, B.A. and Gökmen, V. (2011). Degradation of 5-hydroxymethylfurfural during yeast fermentation. Food Addit. Contam: Part A 28: 1629-1635.

5. Alnouti, Y. and Klaassen, C.D. (2006). Tissue distribution and ontogeny of sulfotransferase enzymes in mice. Toxicol. Sci. 93: $242-255$.

6. Ameur, L.A., Mathieu, O., Lalanne, V., Trystram, G. and Birlouez-Aragon, I. (2007). Comparison of the effects of sucrose and hexose on furfural formation and browning in cookies baked at different temperatures. Food Chem. 101: 1407-1416.

7. Ameur, L.A., Rega, B., Giampaoli, P., Trystram, G. and Birlouez-Aragon, I. (2008). The fate of furfurals and other volatile markers during the baking process of a model cookie. Food Chem. 111: 758-763.

8. Ameur, L.A., Trystram, G. and Birlouez-Aragon, I. (2006). Accumulation of 5-hydroxymethyl-2-furfural in cookies during the backing process: Validation of an extraction method. Food Chem. 98: 790-796.

9. Antal Jr, M.J., Mok ,W.S. and Richards, G.N. (1990). Mechanism of formation of 5-(hydroxymethyl)-2-furaldehyde from D-fructose and sucrose. Carbohydr. Res. 199: 91-109. 
10. An, S.Y., Qian, S.H. and Jiang, J.Q. (2009). Chemical constituents of Sparganium stoloniferum Buch. -Ham. Chin. Wild Plant. Res. 28: 5759.

11. Archer, M.C., Bruce, W.R., Chan, C.C., Corpet, D.E., Medline, A., Roncucci, L., Stamp, D. and Zhang, X.M. (1992). Aberrant crypt foci and microadenoma as markers for colon cancer. Environ. Health Perspect. 98: 195-197.

12. Arribas-Lorenzo, G. and Morales, F.J. (2010). Estimation of dietary intake of 5-hydroxymethylfurfural and related substances from coffee to Spanish population. Food Chem. Toxicol. 48: 644-649.

13. Baggiolini, M. and Clark-Lewis, I. (1992). Interleukin-8, a chemotactic and inflammatory cytokine. FEBS Lett. 307: 97-101.

14. Bali, S., Tofanelli, M.A., Ernst, R.D. and Eyring, E.M. (2012). Chromium (III) catalysts in ionic liquids for the conversion of glucose to 5(hydroxymethyl) furfural (HMF): Insight into metal catalyst: ionic liquid mediated conversion of cellulosic biomass to biofuels and chemicals. Biomass Bioenergy 42: 224-227.

15. Balkwill, F. and Mantovani, A. (2001). Inflammation and cancer: back to Virchow?. The Lancet 357: 539-545.

16. Boopathy, R., Bokang, H. and Daniels, L. (1993). Biotransformation of furfural and 5-hydroxymethyl furfural by enteric bacteria. J. Ind. Microbiol. 11: 147-150.

17. Cao, G., Cai, H., Cai, B. and Tu, S. (2013). Effect of 5-hydroxymethylfurfural derived from processed Cornus officinalis on the prevention of high glucose-induced oxidative stress in human umbilical vein endothelial cells and its mechanism. Food Chem. 140: $273-279$.

18. Cao, G., Ji, J.Y., Cong, X.D., Zhang, Y. and Cai, B.C. (2012). Changes of 5-hydroxymethyl furfuraldehyde contents in Radix Scrophulariae steamed for different times. Chin. J. New Drugs 21: 936-937.

19. Cao, L. (2012). Chemical constituents from Humulus scandens. Chin. J. Ethnomed. Ethnopharm. 21: 24-25.

20. Cao, Y.J., Li, F., Tan, P. and Li, M.L. (2009). Changes of 5-HMF Contents in Ligustrum lucidum Ait before and after Processing. Lishizhen Med. Mater. Med. Res. 20: 2929-2930.

21. Chen, H., Yao, Y., Qiao, L., Zhou, Y.Z., Hua, H.M. and Pei, Y.H. (2008). Chemical constituents from Cynanchum amplexicaule Sieb. et Zucc.. Chin. J. Med. Chem. 18: 51-53.

22. Chen, J., Zhang, W. and Ni, L. (2009). Determination of 5-hydroxymethylfurfural in yellow rice wine by HPLC. Liquor-Making Sci. Technol. (3): 106-108.

23. Chen, L. and Huang, X.S. (2010). Simultaneous Determination of 5-hydroxymethylfurfural and nine kinds of phenolic compounds in rice wine using high performance liquid chromatography. Chin. J. Anal. Chem. 38: 133-137.

24. Chen, Q.T., Zhuo, L.H., Xu, W., Huang, Z.H. and Qiu, X.H. (2012). Content changes of 5 components in Polygohum muhiflorum during processing. Chin. J. Exper. Tradit. Med. Form. 18: 66-71.

25. Chen, Y., Tian, J.K. and Cheng,Y.Y. (2005). Studies on chemical constituents of Ranunculus ternatus. Chin. Pharm. J. 40: $1373-1374$.

26. Cheriot, S., Pöchtrager, C. S., Wagner, K.H. and Nicolas, J. (2009). A comparison study between antioxidant and mutagenic properties of cysteine glucose-derived Maillard reaction products and neoformed products from heated cysteine and hydroxymethyl furfural. Food Chem. 114: $132-138$.

27. Cohen, E., Birk, Y., Mannheim, C.H. and Saguy, I.S. (1998). A rapid method to monitor quality of apple juice during thermal processing. LWT-Food Sci. Technol. 31: 612-616.

28. Damasceno, L.F., Fernandes, F.A., Magalhães, M. and Brito, E.S. (2008). Non-enzymatic browning in clarified cashew apple juice during thermal treatment: Kinetics and process control. Food Chem. 106: 172-179.

29. Dang, Q., Cao, J.Q., Zhang, N., Lv, A.L., Wang, D. and Pei, Y.H. (2007). Isolation and identification of chemical constituents from fruits of Hippophae rhamnoides L.. J. Shenyang Pharm. Univ. 24: 488-490.

30. del Campo, G., Berregi, I., Caracena, R. and Zuriarrain, J. (2010). Quantitative determination of caffeine, formic acid, trigonelline and 5(hydroxymethyl) furfural in soluble coffees by ${ }^{1} \mathrm{H}$ NMR spectrometry. Talanta 81: 367-371.

31. Ding, X., Wang, M.Y., Yao, Y.X., Li, G.Y. and Cai, B.C. (2010). Protective effect of 5-hydroxymethylfurfural derived from processed Fructus Corni on human hepatocyte LO2 injured by hydrogen peroxide and its mechanism. J. Ethnopharmacol. 128: $373-376$.

32. Durling, L.J., Busk, L. and Hellman, B.E. (2009). Evaluation of the DNA damaging effect of the heat-induced food toxicant 5hydroxymethylfurfural (HMF) in various cell lines with different activities of sulfotransferases. Food Chem. Toxicol. 47: 880-884.

33. Du, W.F., Cai, H. and Cai, B.C. (2008). Simultaneous Determination of five active constituents in Comus officinalis by HPLC-DAD. Chin. Pharm. J. 43: 1342-1345.

34. Du, Y., Hong, J., Pan, K., Yan, X. and Zhang, W. (2004). 5-(Hydroxymethyl) furfural and derivatives as inhibitors of TNFalpha and IL1beta production: U.S. Patent Application 10/930,887[P]. 2004-8-30.

35. Fadel, H.H.M. and Farouk, A. (2002). Caramelization of maltose solution in presence of alanine. Amino Acids 22: 199-213.

36. Fang, C.W., Chen, J.J. and Liu, S.J. (2010). Studies on the chemical constituents of rhizoma of Coniogramme japonica. J. Chin. Med. Mater. 33: 557-559.

37. Feng, B.M. and Pei,Y.H. (2000). Chemical constituents of the peels of Citrus grandis. J. Shenyang Pharm. Univ. 17: $332-333$.

38. Galli, S.J., Tsai, M. and Piliponsky, A.M. (2008). The development of allergic inflammation. Nature 454: 445-454.

39. Gaspar, E.M. and Lucena, A.F. (2009). Improved HPLC methodology for food control-furfurals and patulin as markers of quality. Food Chem. 114: 1576-1582.

40. Gentry, T.S. and Roberts, J.S. (2004). Formation kinetics and application of 5-hydroxymethylfurfural as a time-temperature indicator of lethality for continuous pasteurization of apple cider. Innov. Food Sci. Emerg. Technol. 5: 327-333.

41. Glatt, H. and Meinl, W. (2004). Pharmacogenetics of soluble sulfotransferases (SULTs). Naunyn-Schmiedeberg's Arch. Pharmacol. 369: 55-68.

42. Glatt, H., Schneider, H. and Liu, Y. (2005). V79-hCYP2E1-hSULT1A1, a cell line for the sensitive detection of genotoxic effects induced by carbohydrate pyrolysis products and other food-borne chemicals. Mutat. Res./Genet. Toxicol. Environ. Mutag. 580: 41-52.

43. Godfrey, V.B., Chen, L.J., Griffin, R.J., Lebetkin, E.H. and Burka, L.T. (1999). Distribution and metabolism of (5-hydroxymethyl) furfural in male F344 rats and B6C3F1 mice after oral administration. J. Toxicol. Environ. Health, Part A 57: 199-210.

44. Gögüs, F., Düzdemir, C. and Eren, S. (2000). Effects of some hydrocolloids and water activity on nonenzymic browning of concentrated orange juice. Food/Nahrung 44: 438-442.

45. Gökmen, V. and Acar, J. (1999). Simultaneous determination of 5-hydroxymethylfurfural and patulin in apple juice by reversed-phase liquid chromatography. J. Chromatogr. A 47: 69-74.

46. Gökmen, V., Açar, Ö.Ç., Köksel, H. and Acar, J. (2007). Effects of dough formula and baking conditions on acrylamide and hydroxymethyl furfural formation in cookies. Food Chem. 104: 1136-1142. 


\section{http://dx.doi.org/10.4314/ajtcam.v12i2.9}

47. Gökmen, V., Açar, Ö.Ç., Serpen, A. and Morales, F.J. (2008). Effect of leavening agents and sugars on the formation of hydroxymethyl furfural in cookies during baking. Eur. Food Res. Technol. 226: 1031-1037.

48. Gökmen, V. and Şenyuva, H.Z. (2007). Effects of some cations on the formation of acrylamide and furfurals in glucose-asparagine model system. Eur. Food Res. Technol. 225: 815-820.

49. Groke, K., Herwig, R. and Ferdinand, P. (2010). U.S. Patent No. 7,855,191. Washington, DC: U.S. Patent and Trademark Office.

50. Gu, H., Jiang, Z.Q., Jiang, H.Y., Ding, X., Zhan, Z. and Wang, M.Y. (2011a). 5-Hydroxyl methyl-furfural's effect and mechanism on rat with $\mathrm{H}_{2} \mathrm{O}_{2}$ induced hippocampal neurons injuries. J. Nanjing CHM. Univ. 27: 437-440.

51. Gu, H., Jiang, Y.B., Jiang, H.Y., Xu, D.Q., Yu, J.T., Ding, X., Zhao, F.M., Zhan, Z. and Wang, M.Y. (2011b). Effect of 5-hydroxymethyl furfural on BCL-2 and NF-kB gene expression of apoptotic rat hippocampal neurons injured by $\mathrm{H}_{2} \mathrm{O}_{2}$. J. Chin. Med. Mater. 34: $1753-1756$.

52. Guan, J., Cao, Q., Guo, X. and Mu, X. (2011). The mechanism of glucose conversion to 5-hydroxymethylfurfural catalyzed by metal chlorides in ionic liquid: A theoretical study. Comput. Theor. Chem. 963: 453-462.

53. Guo, Y.X., Wen, X.S., Zhao, Y., Wei, G.D. and Sun, P. (2012). Maillard reaction contributing to chemical changes during the processing of Shu Dihuang, the steamed root of Rehmannia glutinosa. Asian J. Tradit. Med. 7: 50-58.

54. Guo, Z.J., Zuo, J.F., Bo, X.Q. and Sun, Q.S. (2007). Study on chemical constituents of Euphorbia hylonoma Hand. -Mazz.. J. Chin. Med. Mater. 30: 412-415.

55. Hodge, J.E. (1953). Dehydrated foods, chemistry of browning reactions in model systems. J. Agric. Food Chem. 1: 928-943.

56. Hou, Y.C., Ching, H., Chao, P.D.L., Tsai, S.Y., Wen, K.C., Hsieh, P.H. and Hsiu, S.L. (2005). Effects of glucose, fructose and 5hydroxymethyl-2-furaldehyde on the presystemic metabolism and absorption of glycyrrhizin in rabbits. J. Pharm. Pharmacol. 57: 247-251.

57. Humes, J.L., Bonney, R.J., Pelus, L., Dahlgren, M.E., Sadowski, S.J., Kuehl, F.A. and Davies, P. (1977). Macrophages synthesise and release prostaglandins in response to inflammatory stimuli. Nature 269: 149-151.

58. Husøy, T., Haugen, M., Murkovic, M., Jöbstl, D., Stølen, L.H., Bjellaas, T., Rønningborg, C., Glatt, H. and Alexander, J. (2008). Dietary exposure to 5-hydroxymethylfurfural from Norwegian food and correlations with urine metabolites of short-term exposure. Food Chem. Toxicol. 46: 3697-3702.

59. Jadhav, H., Taarning, E., Pedersen, C.M. and Bols, M. (2012). Conversion of D-glucose into 5-hydroxymethylfurfural (HMF) using zeolite in [Bmim] $\mathrm{Cl}$ or tetrabutylammonium chloride $(\mathrm{TBAC}) / \mathrm{CrCl}_{2}$. Tetrahedron Lett. 53: 983.

60. Janzowski, C., Glaab,V., Samimi, E., Schlatter, J. and Eisenbrand, G. (2000). 5-Hydroxymethylfurfural: assessment of mutagenicity, DNAdamaging potential and reactivity towards cellular glutathione. Food Chem. Toxicol. 38: 801-809.

61. Jia, T.Z., Chen, H.L., Xie, S.Q., Zhou, H. and Li, G.Y. (2002). Analysis of 5-hydroxymethylfurfural in sublimate of cibot rhizome. Chin. Tradit. Patent Med. 24: 768-771.

62. Jöbstl, D., Husøy, T., Alexander, J., Bjellaas, T., Leitner, E. and Murkovic, M. (2010). Analysis of 5-hydroxymethyl-2-furoic acid (HMFA) the main metabolite of alimentary 5-hydroxymethyl-2-furfural (HMF) with HPLC and GC in urine. Food Chem. 123: 814-818.

63. Kim, H.K., Choi, Y.W., Lee, E.N., Park, J.K., Kim, S.G., Park, D.J., Kim, B.S., Lim, Y.T. and Yoon, S. (2011). 5-Hydroxymethylfurfural from black garlic extract prevents TNF $\alpha$-induced monocytic cell adhesion to HUVECs by suppression of vascular cell adhesion molecule-1 expression, reactive oxygen species generation and NF- $\kappa$ B activation. Phytother. Res. 25: 965-974.

64. Kitts, D.D., Chen, X.M. and Jing, H. (2012). Demonstration of antioxidant and anti-inflammatory bioactivities from sugar-amino acid Maillard reaction products. J. Agric. Food Chem. 60: 6718-6727.

65. Kroh, L.W. (1994). Caramelisation in food and beverages. Food Chem. 51: 373-379.

66. Kröncke, K.D., Fehsel, K. and Kolb-Bachofen,V. (1998). Inducible nitric oxide synthase in human diseases. Clin. Exper. Immunol. 113: $147-156$.

67. Lavelli, V. and Vantaggi, C. (2009). Rate of antioxidant degradation and color variations in dehydrated apples as related to water activity. J. Agric. Food Chem. 57: 4733-4738.

68. Lewkowski, J. (2001). Synthesis, chemistry and applications of 5-hydroxymethylfurfural and its derivatives. Arkivoc 1: 17-54.

69. Li, F., Zhou, B.H., Yan, X.G., Duan, L.X., Feng, B.M. and Wang, Y.Q. (2008). Study on the chemical constituents of Urtica angustifolia Fisch. ex Hornem. Chin. Hosp. Pharm. J. 28: 873-874.

70. Li, H.M., Bai, H., Li, W., Wang, Y.S. and Zhao, H.X. (2010). Study on chemical constituents of Polygonatum odoratum (Mill.) Druce. Food Drug 12: 102-104.

71. Li, H.X., Pan, Q.C., Xian, L.J. and Liu, Z.C. (1993). Investigation on a new anticancer drug screening method, using DNA polymerase as a target. Cancer 12: 473-475.

72. Li, J., Zhang, L.P., Liu, W., Zhang, Z.L. and Liu, L.J. (2005). Studies on the changes of 5-hydroxymethyl furfuraldehyde content in Radix Rehmanniae steamed for different time. China J. Chin. Mater. Med. 30: 1438-1440.

73. Li, M.M., Wu, L.Y., Zhao, T., Wu, K.W., Xiong, L., Zhu, L.L. and Fan, M. (2011a). The protective role of 5-hydroxymethyl-2-furfural (5HMF) against acute hypobaric hypoxia. Cell Str. Chap. 16: 529-537.

74. Li, M.M., Wu, L.Y., Zhao, T., Xiong, L., Huang, X., Liu, Z.H., Fan, X.L., Xiao, C.R., Gao,Y., Ma, Y.B., Chen, J.J., Zhu, L.L. and Fan, M. (2011b). The protective role of 5-HMF against hypoxic injury. Cell Str. Chap. 16: 267-273.

75. Li, X., Wang, J.H., Meng, D.L. and Li, X. (2003). Chemical constituents of Atractylodes chinensis (DC.) Koidz. roasted with bran. J. Shenyang Pharm. Univ. 20: 173-175.

76. Lin, A.S., Qian, K., Usami, Y., Lin, L., Itokawa, H., Hsu, C., Morris-Natschke, S.L. and Lee, K.H. (2008). 5-Hydroxymethyl-2-furfural, a clinical trials agent for sickle cell anemia, and its mono/di-glucosides from classically processed steamed Rehmanniae Radix. J. Nat. Med. 62: 164-167.

77. Lin, S.M., Wu, J.Y., Su, C., Ferng, S., Lo, C.Y. and Chiou, R.Y.Y. (2012). Identification and mode of action of 5-hydroxymethyl-2-furfural (5-HMF) and 1-methyl-1, 2, 3, 4-tetrahydro- $\beta$-carboline-3-carboxylic acid (MTCA) as potent xanthine oxidase inhibitors in vinegars. J. Agric. Food Chem. 60: 9856-9862.

78. Ling, J.H., Wang, J.H., Wang, N., Li, W., Sha, Y. and Li, X. (2005). Studies on the chemical constituents of Malt. J. Shenyang Pharm. Univ. 22: 267-270.

79. Liu, D.D. and Chen, E.Y.X. (2013). Polymeric ionic liquid (PIL)-supported recyclable catalysts for biomass conversion into HMF. Biomass Bioenergy 48: 181-190.

80. Liu, H.L., Wu, L.J., Li, H. and Wang, J. (2002). Study on the chemical constituents of Isatis indigotica Fort. J. Shenyang Pharm. Univ. 19: 93-95. 


\section{http://dx.doi.org/10.4314/ajtcam.v12i2.9}

81. Liu, M.L., Bai, M., Bai, R.Z. and Feng, H.L. (1995). Studies on processing adhesive Rehmannia (Rehmannia glutinnosa) 1. Extraction, separation, identification and assay of 5-hydroxymethyl-furfural. J. Chin. Herb. Med. 26: 13-14.

82. Liu, X.Q., Li, L.L., Ni, N. and Zheng, L.S. (2011). Chemical constituents and quantitative analysis of Angelica acutiloba Kitag. Nat. Prod. Res. Dev. 23: 693-695.

83. Liu, Z.L., Slininger, P.J. and Gorsich, S.W. (2005). Enhanced biotransformation of furfural and hydroxymethylfurfural by newly developed ethanologenic yeast strains. Twenty-Sixth Symposium on Biotechnology for Fuels and Chemicals, Humana Press. 451-460.

84. Liu, Z.L., Song, Z.Q., Chao, Z.M., Lv, S.Y., Wang, C. and Li, L.F. (2008). HPLC determination of chemical constituents produced in Radix Polygoni multiflori after processing. China J. Chin. Mater. Med. 33: 2326-2329.

85. Lorne, E., Zmijewski, J.W., Zhao, X., Liu, G., Tsuruta, Y., Park, Y.J., Dupont, H. and Abraham, E. (2008). Role of extracellular superoxide in neutrophil activation: interactions between xanthine oxidase and TLR4 induce proinflammatory cytokine production. Am. J. Physiol.-Cell Physiol. 294: C985-C993.

86. Lu, K., Cao, W. and Zheng, J.B. (2006). Effects of thermal treatment on 5-hydroxymethyl-2-furaldehyde(HMF) contents in different floral honeys. J. Northwest Univ. (Nat. Sci. Edit.) 36: 253-256.

87. Maes, P., Monakhova,Y.B., Kuballa,T., Reusch, H. and Lachenmeier, D.W. (2012). Qualitative and quantitative control of carbonated cola beverages using ${ }^{1}$ H-NMR spectroscopy. J. Agric. Food Chem. 60: 2778-2784.

88. Marko, D., Habermeyer, M., Kemény, M., Weyand, U., Niederberger, E., Frank, O. and Hofmann, T. (2003). Maillard reaction products modulating the growth of human tumor cells in vitro. Chem. Res. Toxicol. 16: 48-55.

89. Marko, D., Kemeny, M., Bernady, E., Habermeyer, M., Weyand, U., Meiers, S., Frank, O. and Hofmann, T. (2002). Studies on the inhibition of tumor cell growth and microtubule assembly by 3-hydroxy-4-[(E)-(2-furyl) methylidene] methyl-3-cyclopentene-1, 2-dione, an intensively coloured Maillard reaction product. Food Chem. Toxicol. 40: 9-18.

90. Martins, S.I. and Van Boekel, M.A. (2005). A kinetic model for the glucose/glycine Maillard reaction pathways. Food Chem. 90: 257-269.

91. Matsuda, E., Yoshizawa, Y., Yokosawa, Y., Watanabe, N., Kawaii, S. and Murofushi, N. (2006). Effects of Eucommia ulmoides Oliver leaf extract on 3T3-L1 differentiation into adipocytes. J. Nat. Med. 60: 126-129.

92. Matsuda, H., Tsukioka, Y. and Moriyama, K. (2004). Studies on Rehmanniae Radix. V. 5-hydroxymethyl-2-furaidehude, active constituent of the steamed root of rehmannia glutinosa having increasing activity of erythrocyte deformability in rats. Nat. Med. 58: 34-37.

93. Michail, K., Matzi, V., Maier, A., Herwig, R., Greilberger, J., Juan, H., Kunert, O. and Wintersteiger, R. (2007). Hydroxymethylfurfural: an enemy or a friendly xenobiotic? A bioanalytical approach. Anal. Bioanal. Chem. 387: 2801-2814.

94. Mishra, O.P., Zubrow, A.B. and Ashraf, Q.M. (2004). Nitric oxide-mediated activation of extracellular signal-regulated kinase (ERK) and c-jun N-terminal kinase (JNK) during hypoxia in cerebral cortical nuclei of newborn piglets. Neuroscience 123: 179-186.

95. Miyazawa, M., Anzai, J., Fujioka, J. and Isikawa, Y. (2003). Insecticidal compounds against Drosophila melanogaster from Cornus officinalis Sieb. et Zucc. Nat. Prod. Res. 17: 337-339.

96. Mizushina, Y., Yagita, E., Kuramochi, K., Kuriyama, I., Shimazaki, N., Koiwai, O., Uchiyama, Y., Yomezawa, Y., Sugawara, F., Kobayashi, S., Sakaguchi, K. and Yoshida, H. (2006). 5-(Hydroxymethyl)-2-furfural: A selective inhibitor of DNA polymerase $\lambda$ and terminal deoxynucleotidyltransferase. Arch. Biochem. Biophys. 446: 69-76.

97. Modig, T., Lidén, G. and Taherzadeh, M. (2002). Inhibition effects of furfural on alcohol dehydrogenase, aldehyde dehydrogenase and pyruvate dehydrogenase. Biochem. J. 363: 769-776.

98. Monakhova, Y.B. and Lachenmeier, D.W. (2012).The margin of exposure of 5-hydroxymethylfurfural (HMF) in alcoholic beverages. Environ. Health Toxicol. 27: e2012016.

99. Monien, B.H., Engst, W., Barknowitz, G., Seidel, A. and Glatt, H. (2012). Mutagenicity of 5-hydroxymethylfurfural in V79 cells expressing human SULT1A1: identification and mass spectrometric quantification of DNA adducts formed. Chem. Res. Toxicol. 25: 14841492.

100. Monien, B.H., Frank, H., Seidel, A. and Glatt, H. (2009). Conversion of the common food constituent 5-hydroxymethylfurfural into a mutagenic and carcinogenic sulfuric acid ester in the mouse in vivo. Chem. Res. Toxicol. 22: 1123-1128.

101. Morales, V., Sanz, M.L., Martín-Álvarez, P.J. and Corzo, N. (2009). Combined use of HMF and furosine to assess fresh honey quality. J. Sci. Food Agric. 89: 1332-1338.

102. Murkovic, M. and Bornik, M.A. (2007). Formation of 5-hydroxymethyl-2-furfural (HMF) and 5-hydroxymethyl-2-furoic acid during roasting of coffee. Mol. Nutr. Food Res. 51: 390-394.

103. Murkovic, M. and Pichler, N. (2006). Analysis of 5-hydroxymethylfurfual in coffee, dried fruits and urine. Mol. Nutr. Food Res. 50: 842846.

104. Okano, T., Qiao, K., Bao, Q., Tomida, D., Hagiwara, H. and Yokoyama, C. (2012). Dehydration of fructose to 5-hydroxymethylfurfural (HMF) in an aqueous acetonitrile biphasic system in the presence of acidic ionic liquids. Appl. Catal. A: General 451: 1-5.

105. Oliviero, T., Capuano, E., Cämmerer, B. and Fogliano,V. (2008). Influence of roasting on the antioxidant activity and HMF formation of a cocoa bean model systems. J. Agric. Food Chem. 57: 147-152.

106. Perez Locas, C. and Yaylayan, V.A. (2008). Isotope labeling studies on the formation of 5-(hydroxymethyl)-2-furaldehyde (HMF) from sucrose by pyrolysis-GC/MS. J. Agric. Food Chem. 56: 6717-6723.

107. Pettersen, J.E. and Jellum, E. (1972). The identification and metabolic origin of 2-furoylglycine and 2, 5-furandicarboxylic acid in human urine. Clin. Chim. Acta 41: 199-207.

108. Qin, W.J., Wang, G.L. and Lin, R.C. (2007). Studies on chemical constituents of Heterosmilax yunnanensis (II). Chin. Tradit. Herb. Drugs 38: $1466-1468$.

109. Quintas, M.A., Brandao, T.R. and Silva, C.L. (2007). Modelling colour changes during the caramelisation reaction. J. Food Eng. 83: 483491.

110. Rajabbeigi, N., Ranjan, R. and Tsapatsis, M. (2012). Selective adsorption of HMF on porous carbons from fructose/DMSO mixtures. Microporous Mesoporous Mater. 158: 253-256.

111. Ramírez-Jiménez, A., García-Villanova, B. and Guerra-Hernández, E. (2001). Effect of toasting time on the browning of sliced bread. J. Sci. Food Agric. 81: 513-518.

112. Ramirez-Jimenez, A., Guerra-Hernández, E. and García-Villanova, B. (2000). Browning indicators in bread. J.Agric. Food Chem. 48: 41764181.

113. Ren, F.X., Zhang, A.J. and Zhao,Y.M. (2010). Study on the chemical constituents of Pyrola calliantha H. Andres. Nat. Prod. Res. Dev. 22: 54-57. 
114. Rivero-Cruz, J.F., Zhu, M., Kinghorn, A.D. and Wu, C.D. (2008). Antimicrobial constituents of Thompson seedless raisins (Vitis vinifera) against selected oral pathogens. Phytochem. Lett. 1: 151-154.

115. Román-Leshkov, Y., Chheda, J.N. and Dumesic, J.A. (2006). Phase modifiers promote efficient production of hydroxymethylfurfural from fructose. Science 312: 1933-1937.

116. Rosatella, A.A., Simeonov, S.P., Frade, R.F. and Afonso, C.A. (2011). 5-Hydroxymethylfurfural (HMF) as a building block platform: Biological properties, synthesis and synthetic applications. Green Chem. 13: 754-793.

117. Rufián-Henares, J.A. and de la Cueva, S.P. (2009). Antimicrobial activity of coffee melanoidins : a study of their metal-chelating properties. J. Agric. Food Chem. 57: 432-438.

118. Rufián-Henares, J.A. and Morales, F.J. (2007a). Functional properties of melanoidins: In vitro antioxidant, antimicrobial and antihypertensive activities. Food Res. Int. 40: 995-1002.

119. Rufián-Henares, J.A. and Morales, F.J. (2007b). Angiotensin-I converting enzyme inhibitory activity of coffee melanoidins. J. Agric. Food Chem. 55: 1480-1485.

120. Rufián-Henares, J.A. and Morales, F.J. (2008). Antimicrobial activity of melanoidins against Escherichia coli is mediated by a membranedamage mechanism. J. Agric. Food Chem. 56: 2357-2362.

121. Safo, M.K., Abdulmalik, O., Danso-Danquah, R., Burnett, J.C., Nokuri, S., Joshi, G.S., Musayev, F.N., Asakura, T. and Abraham, D.J. (2004). Structural basis for the potent antisickling effect of a novel class of five-membered heterocyclic aldehydic compounds. J. Med. Chem. 47: 4665-4676.

122. Saikumar, P. and Venkatachalam, M.A. (2003). Role of apoptosis in hypoxic/ischemic damage in the kidney. Sem. Nephrol. 23: 511-521.

123. Sehnem, N.T., Machado, A.D.S., Leite, F.C.B., Pita, W.D.B. and Ayub, M.A.Z. (2013). 5-hydroxymethylfurfural induces ADH7 and ARI1 expression in tolerant industrial Saccharomyces cerevisiae strain P6H9 during bioethanol production. Bioresour. Technol. 133: 190-196.

124. Seol, J.W., Lee, H.B., Lee, Y.J., Lee, Y.H., Kang, H.S., Kim, I.S., Kim, N.S. and Park, S.Y. (2009). Hypoxic resistance to articular chondrocyte apoptosis-a possible mechanism of maintaining homeostasis of normal articular cartilage. FEBS J. 276: $7375-7385$.

125. Severin, I., Dumont, C., Jondeau-Cabaton, A., Graillot , V. and Chagnon, M.C. (2010). Genotoxic activities of the food contaminant 5hydroxymethylfurfural using different in vitro bioassays. Toxicol. Lett. 192: 189-194.

126. Shang, Z.P., Zhao, Q.C., Tan, J.J., Yang, L., Yan, M. and Shi, G.B. (2010). Chemical constituents from rhizomes of Drynaria fortune. Pract. Pharm. Clin. Remed. 13: 262-263.

127. Sharma, V.K., Choi, J., Sharma, N., Choi, M. and Seo, S.Y. (2004). In vitro anti-tyrosinase activity of 5-(hydroxymethyl)-2-furfural isolated from Dictyophora indusiata. Phytother. Res. 18: 841-844.

128. Shi, B.J., Jiang, H.F., Zhao, B.T. and Zhang, W.M. (2010). Study on chemical constituents of Typhonium giganteum. Chin. Wild Plant Resour. 29: 38-39.

129. Shi, S.P., Jiang, D., Dong, C.X. and Tu, P.F. (2007). Chemical constituents of Clematis manshurica. Chin. Tradit. Herb Drugs 38: $335-337$.

130. Sionneau, P. and Flaws, B. (1995). Pao Zhi: An introduction to the use of processed Chinese medicinals. Boulder CO: Blue Poppy Press.

131. Song, Y.R., Liu, Y., Le, G.W., Zhang, R. and Shi, Y.H. (2010). Study on antioxidation capability of fructose-oligosaccharide and 5hydroxymethylfurfural. Sci. Technol. Food Ind. 31: 342-345.

132. Spano, N., Casula, L., Panzanelli, A., Pilo, M.I., Piu, P.C., Scanu, R., Tapparo, A. and Sanna, G. (2006). An RP-HPLC determination of 5hydroxymethylfurfural in honey: the case of strawberry tree honey. Talanta. 68: 1390-1395.

133. Sun, B.H., Jichuan, Y.Z., Chen, Y.J. and Wu, L.J. (2006). Chemical constituents of Stellaria dichatoma L.var. lanceolata Bge. J. Shenyang Pharm. Univ. 23: 84-87.

134. Sun, K., Li, X., Kang, X.D. and Liu, L. (2005). Study on chemical constituents of Descurainia Sophia (L.) Webb ex Prantl. J. Shenyang Pharm. Univ. 22: 181-182.

135. Sun, Y.J., Li, Z.L., Chen, H., Zhou, W. and Hua, H.M. (2012). Study on chemical constituents from the roots and rhizomes of Sinopodophyllum emodi. J. Chin. Med. Mater. 35: 1607-1609.

136. Surh, Y.J. and Tannenbaum, S.R. (1994). Activation of the Maillard reaction product 5-(hydroxymethyl) furfural to strong mutagens via allylic sulfonation and chlorination. Chem. Res. Toxicol. 7: 313-318.

137. Svendsen, C., Husøy, T., Glatt, H., Paulsen, J.E. and Alexander, J. (2009). 5-Hydroxymethylfurfural and 5-sulfooxymethylfurfural increase adenoma and flat ACF number in the intestine of Min/+ mice. Anticancer Res. 29: 1921-1926.

138. Taherzadeh, M.J., Gustafsson, L., Niklasson, C. and Lidén, G. (2000). Physiological effects of 5-hydroxymethylfurfural on Saccharomyces cerevisiae. Appl. Microbiol. Biotechnol. 53: 701-708.

139. Theobald, A., Müller, A. and Anklam, E. (1998). Determination of 5-hydroxymethylfurfural in vinegar samples by HPLC. J. Agric. Food Chem. 46: 1850-1854.

140. Tong, X.G. and Cheng, Y.X. (2011). Chemical constituents from Acorus tatarinowii. Nat. Prod. Res. Dev. 23: 404-409.

141. Vaikousi, H., Koutsoumanis, K. and Biliaderis, C.G. (2008). Kinetic modelling of non-enzymatic browning of apple juice concentrates differing in water activity under isothermal and dynamic heating conditions. Food Chem. 107: 785-796.

142. Verhaegen, S., McGowan, A.J., Brophy, A.R., Fernandes, R.S. and Cotter,T.G. (1995). Inhibition of apoptosis by antioxidants in the human HL-60 leukemia cell line. Biochem. Pharmacol. 50: 1021-1029.

143. Villela, N.R., Cabrales, P., Tsai, A.G. and Intaglietta, M. (2009). Microcirculatory effects of changing blood hemoglobin oxygen affinity during hemorrhagic shock resuscitation in an experimental model. Shock 31: 646-653.

144. Vorbach, C., Harrison, R. and Capecchi, M.R. (2003). Xanthine oxidoreductase is central to the evolution and function of the innate immune system. Trends Immunol. 24: 512-517.

145. Wang, C.H., Wang, Y., Wang, G.C., Ya, J., Zhang, X.Q. and Ye, W.C. (2008). Chemical constituents from roots of Millettia speciosa. Chin. Tradit. Herb. Drugs 39: 972-975.

146. Wang, F., Cui, H.H. and Wang, S.M. (2011a). Studies on chemical constituents of storax. Chin. J. Exper. Tradit. Med. Form. 17: 89-91.

147. Wang, H.Y., Qian, H. and Yao,W.R. (2011b). Melanoidins produced by the Maillard reaction: structure and biological activity. Food Chem. 128: $573-584$.

148. Wang, J., Li, H.Y., Zhang, B.S. and Xu, H.Y. (2011c). Influence of heat treatment on 5-HMF of Chinese jujube juice. J. Shanxi Normal Univ. (Nat. Sci. Edit.) 39: 91-95.

149. Wang, L., Luo, H.S. and Xia, H. (2009a). Sodium butyrate induces human colon carcinoma HT-29 cell apoptosis through a mitochondrial pathway. J. Int. Med. Res. 37: 803-811. 
150. Wang, M.Y., Zhao, F.M., Peng, H.Y., Lou, C.H., Li, Y., Ding, X., Yu, X.Y., Yang, G.M., Xu, D.Q., Jiang, L.H., Zhang, X., Ye, L.H. and Cai, B.C. (2010). Investigation on the morphological protective effect of 5-hydroxymethylfurfural extracted from wine-processed Fructus corni on human L02 hepatocytes. J. Ethnopharmacol. 130: 424-428.

151. Wang, Q.H., Li, X. and Wang, J.H. (2009b). Study on the constituents of ophiopogonis tuber. Mod. Chin. Med. 11: 21-22.

152. Wang, X., Tang, S.A., Zhai, H.Y. and Duan, H.Q. (2011d). Studies on anti-tumor metastatic constituents from Ardisia crenata. China J. Chin. Mater. Med. 36: 881-885.

153. Wikandari, R., Millati, R., Syamsiyah, S., Muriana, R. and Ayuningsih, Y. (2010). Effect of furfural, hydroxymethyl furfural and acetic acid on indigeneous microbial isolate for bioethanol production. Agric. J. 5: 105-109.

154. Wilson, M.H., Newman, S. and Imray, C.H. (2009). The cerebral effects of ascent to high altitudes. Lancet Neurol. 8: 175-191.

155. Xie, F., Zhang, M., Zhang, C.F., Wang, Z.T. and Yu, B.Y. (2008). Studies on chemical constituents in fruit of Melia toosendan. Chin. Pharm. J. 43: 1066-1069.

156. Ya, B.L., Zhang, L., Zhang, L., Li, Y.L. and Li, L. (2012). 5-hydroxymethyl-2-furfural prolongs survival and inhibits oxidative stress in a mouse model of forebrain ischemia. Neur. Regener. Res. 7: 1722-1728.

157. Yalcin, O. and Cabrales, P. (2012). Increased hemoglobin $\mathrm{O}_{2}$ affinity protects during acute hypoxia. Am. J. Physiol., Heart Circ. Physiol. 303: $\mathrm{H} 271$.

158. Yamada, P., Nemoto, M., Shigemori, H., Yokota, S. and Isoda, H. (2011). Isolation of 5-(hydroxymethyl) furfural from Lycium chinense and its inhibitory effect on the chemical mediator release by basophilic cells. Planta Med.-Nat. Prod. Med. Plant. Res. 77: 434.

159. Yang, H., Chou, G.X., Wang, Z.T. and Hu, Z.B. (2007). Studies on chemical constituents of tuber of Pinellia ternate. Chin. Pharm. J. 42: 99-101.

160. Yang, Y., Xu, M., Feng, Y.X. and He, H.H. (2008). Determination of 5-hydroxymethylfurfuraldehyde in different processed products of Polygonatum. J. Chin. Med. Mater. 31: 17-19.

161. Yang, Z.X., Yang, L. and Yang,Y. (2009). Isolation and identification of water-soluble compounds from Zantedeshia aethiopica. Centr. South Pharm. 7: 11-13.

162. Yin, H.Q., Qi, X.L., Hua, H.M. and Pei, Y.H. (2005). The chemical constituents from Saussurea lappa C.B Clarke. Chin. J. Med. Chem. 15: 217-220.

163. Yuan, G.J. and Du, F.L. (2000). Studies on Chemical constituents of the fruits of Rosa bracteata var. bracteata. J. Chin. Med. Mater. 23: 454-456.

164. Yuan, J.Z., Wu, L.J., Chen, Y.J., Li, W., Xiaochi, Y.N. and Erjie, T.B. (2004). Isolation, identification of the chemical constituents from Smilax glabra Roxb.. Chin. J. Med. Chem. 14: 291-293.

165. Zappala, M., Fallico, B., Arena, E. and Verzera, A. (2005). Methods for the determination of HMF in honey: a comparison. Food Contr. 16: 273-277.

166. Zaugg, R.H., Walder, J.A. and Klotz, I.M. (1997). Schiff base adducts of hemoglobin modifications that inhibit erythrocyte sickling. J. Biol. Chem. 252: 8542-8548.

167. Zeng, Z.L., Ye, Z.X., Wan, D.M., Xiong, T. and Peng, S.S. (2002). The effect on the content of HMF of honey by heating process. J. Nanchang Univ. (Nat. Sci.) 26: 67-70.

168. Zhang, D.S., Huang, S.W., Gao, H.Y., Sun, B.H., Huang, J. and Wu, L.J. (2008a). Isolation and identification of chemical constituents from Castanea mollissima Blume. J. Shenyang Pharm. Univ. 25: 454-455.

169. Zhang, H.W. and Zhang, Z.L. (2009). Effect of processing on 5-hydroxymethylfurfural in traditional Chinese medicine. China Pract. Med. 4: 149-151.

170. Zhang, H.W., Zhang, Z.L. and Liu, B. (2010). Isolation and identification of the newly added chemical constituent from processed Rhizoma Typhonii. Lishizhen Med. Mater. Med. Res. 21: 1197-1198.

171. Zhang, J.C., Shen,Y., Zhu, G.Y. and Yang, M.S. (2007). Studies on chemical constituents from Cremastra appendiculata. J. Hebei Univ. (Nat.Sci. Edit.) 27: 262-264.

172. Zhang, L.N. and Jin, G.Q. (2012). Influence of Rehmannia glutinosa's 5-HM F on protein expression of GCR, BDNF, SGK in hippocampal neurons with corticosterone injury. CJCHMP. 27: 853-857.

173. Zhang, L.Z., Wu, H., Li, W., Wen, H.M. and Cui, X.B. (2012a). Determination of 5-(hydroxymethyl) furfural and furfural in different processed products of Coix seeds by HPLC. Pharm. Clin. Res. 20: 574-576.

174. Zhang, R.Y., Piao, J.H., Chu, J., Xu, Y.L. and Li, L. (2008b). Effects of hydroxymethyl-furfural on damages of nerve cell morphology and cytoskeleton system induced by okadaic acid. Tradit. Chin. Drug Res. Clin. Pharmacol. 19: 417-421.

175. Zhang, R.Y., Piao, J.H., Zhang, L., Chu, J., Xu, Y.L. and Li, L. (2008c). Effects and mechanisms of hydroxymethylfurfural on nerve cell injury induced by sodium azide. Chin. Pharmacol. Bull. 24: 1464-1469.

176. Zhang, T. and Chen, R.Y. (2011). Study on chemical constituents in roots of Inula racemosa. Chin. Pharm . J. 46: 1159-1162.

177. Zhang, Z., Liu, B. and Zhao, Z.K. (2012b). Conversion of fructose into 5-HMF catalyzed by $\mathrm{GeCl}_{4}$ in $\mathrm{DMSO}$ and $[\mathrm{Bmim}] \mathrm{Cl}$ system at room temperature. Carbohydr. Polym. 88: 891-895.

178. Zhao, L., Zhang, L., Li, Y.L., Zhang, L. and Li, L. (2007). Effect of 5-hydroxymethylfurfural on learning-memory and brain free radical metabolism in cerebral ischemia-reperfusion model mice. China Pharm. 18: 974-976.

179. Zheng, C.H., Fu, H.W. and Pei, Y.H. (2005). Isolation and identification of the chemical constituents from Bolbostemma paniculatum (Maxim.) Franquet. Chin. J. Med. Chem. 15: 291-293.

180. Zhou, L., Liang, R., Ma, Z., Wu, T. and Wu, Y. (2012a). Conversion of cellulose to HMF in ionic liquid catalyzed by bifunctional ionic liquids. Bioresour. Technol. 129: 450-455.

181. Zhou, T.T., Yang, R.X., Song, Y., Zhang, Y.Y., Lv, Q., Ni, Y.Y. and Li, Q.H. (2012b). Determination of 5-hydroxymethylfurfural (5-HMF) in over mature vinegar by HPLC. Sci. Technol. Food Ind. 33: 83-85.

182. Zhou, Y., Wang, H., Yang, R., Huang, H., Sun,Y., Shen,Y., Lei, H. and Gao, H. (2012c). Effects of Litchi chinensis fruit isolates on prostaglandin E2 and nitric oxide production in J774 murine macrophage cells. BMC Complem. Altern. Med. 12: 12.

183. Zhou, Y.Z., Chen, H., Qiao, L., Hao, D.F., Hua, H.M. and Pei, Y.H. (2007). Chemical constituents from Carthamus tinctorius L.. Chin. J. Med. Chem. 17: 380-382.

184. Zhu, M.J., Tan, N.H., Xiong, J.Y., Ji, C.J., Zhu, H.Z., Xu, J.J. and Luo, Q.j. (2012). Chemical constituents contained in ethanol extracts from Acorus tatarinowii and their anti-fatigue activity. China J. Chin. Mater. Med. 37: 2898-2901. 